\title{
ANALISIS PENGARUH CASH RATIO, DEBT TO EQUITY RATIO DAN RETURN ON ASSET TEHADAP DIVIDENT PAYOUT RATIO PADA PERUSAHAAN MANUFAKTUR YANG TERDAFTAR DI BURSA EFEK INDONESIA PERIODE 2012-2014
}

\author{
Mufidah \\ fiidha.minhocha17@gmail.com \\ Universitas Ahmad Dahlan \\ Rikha Muftia Khorunnisa \\ rikha@mgm.uad.ac.id \\ Universitas Ahmad Dahlan
}

\begin{abstract}
ABSTRAK
This study aims to determine the effect of cash position, debt to equity ratio, and return on assets to the dividend payout ratio of the company automotive manufacturing sector, food and beverage sector, cigarette sector, sector ceramics, cement sector, cable sector and electronics sector which are listed on the Exchange Indonesian Securities 2012-2014 period. The sample in this study is manufacturing companies, automotive sector, food and beverage sector, sector cigarette, ceramic sector, cement sector, cable sector and electronics sector. Technique sampling using purposive sampling technique obtained 17 the sample. Hypothesis test results using multiple linear regression showed that partially cash position and return on assets affect dividend payout ratio, while the debt to equity ratio has no effect on dividend payout ratio, while simultaneous cash positions, debt to equity andreturn on assets affects the dividend payout ratio.
\end{abstract}

Keywords: Cash Position; Debt To Equity Ratio; Return On Assets; Dividend Payout Ratio.

\footnotetext{
PENDAHULUAN

Perkembangan ekonomi suatu negara dapat diukur dengan banyak cara. Salah satunya dengan mengetahui tingkat perkembangan pasar modal dan industriindustri sekuritas pada negara tersebut. Pasar modal (capital market) merupakan pasar untuk berbagai instrumen keuangan jangka panjang yang dapat diperjualbelikan, baik dalam bentuk uang, ekuitas dan instrumen derikatif (Darmaji, 2006). Dalam aktivitas di pasar modal, para investor memiliki harapan dari investasi yang dilakukannya, yaitu berupa capital gain dan dividen. Capital gain merupakan selisih antara harga beli dan harga jual. Capital gain terbentuk karena adanya aktivitas perdagangan saham di
}

pasar sekunder. Dividen merupakan aliran kas yang dibayarkan kepada para pemegang saham (equity investors) (Widiyatmoko, 2013).

Dalam setiap kegiatan investasi yang dilakukan oleh investor, tidak selalu menghasilkan keuntungan sesuai dengan yang diharapkan, karena besar kecilnya keuntungan yang diperoleh dari investasi ditentukan oleh bagaimana kinerja perusahaan. Jika kinerja perusahaan tersebut baik maka kemungkinan dividen yang diberikan semakin banyak, begitu juga sebaliknya apabila kinerja perusahaan buruk maka kemungkinan dividen yang diberikan hanya sedikit bahkan mungkin tidak mendapatkan dividen sama sekali jik perusahaan tersebut pailit (Marlina, 2009). 
Dividen adalah laba yang diberikan emiten kepada para pemegang saham. Dari laba bersih perusahaan, sebagian akan dibagikan kepada para pemegang saham dalam bentuk dividen dan sebagian disisihkan menjadi laba ditahan (retaind earning). Laba ditahan merupakan salah satu sumber untuk membiayai pertumbuhan perusahaan. Kebijakan pembayaran dividen mempunyai pengaruh bagi pemegang saham dan perusahaan yang membayar dividen. Para pemegang saham umumnya menginginkan pembagian dividen yang relatif stabil karena dividen akan meningkatkan kepercayaan pemegang saham terhadap perusahaan sehingga mengurangi ketidakpastian pemegang saham dalam menanamkan dananya ke dalam perusahaan. Bagi perusahaan, untuk membagikan laba dalam bentuk laba ditahan maka kemampuan pembentukan dana internalnya akan semakin besar yang akan dapat digunakan untuk membiayai aktivitas perusahaan sehingga mengurangi ketergantungan perusahaan terhadap dana eksternal dan sekaligus akan memperkecil risiko perusahaan (Marlina, 2009).

Kebijakan dividen merupakan keputusan perusahaan apakah laba yang diperoleh dibagikan kepada para pemegang saham sebagai dividen atau ditahan dalam bentuk laba ditahan (retained earning). Kebijakan dividen perusahaan tergambar pada dividend payout ratio yaitu persentase laba yang dibagikan dalam bentuk dividen tunai, artinya semakin kecilnya pembiayaan investasi di masa yang akan datang. Apabila perusahaan memilih untuk membagikan laba sebagai dividen maka akan mengurangi laba ditahan yang selanjutnya mengurangi total sumber dana internal atau internal financing. Sebaliknya jika perusahaan menahan untuk menambah laba yang diperoleh, maka kemampuan pembentukan dan internal akan semakin besar. Persentase laba yang dibayarkan perusahaan dalam bentuk dividen tunai pada pemegang saham disebut dengan rasio pembayaran atau yang sering disebut dividend payout ratio (Sartono, 2001). Dividend payout ratio akan mempengaruhi keputusan investasi para pemegang saham dan disisi lain berpengaruh pada kondisi keuangan perusahaan. Pertimbangan mengenai dividend payout ratio ini diduga sangat berkaitan dengan kinerja keuangan perusahaan. Bila kinerja perusahaan bagus maka perusahaan tersebut akan mampu menetapkan besarnya dividend payout ratio sesuai dengan harapan pemegang saham dan tentu saja tanpa mengabaikan kepentingan perusahaan untuk tetap sehat dan tumbuh (Marlina, 2009).

Posisi kas atau likuiditas dari suatu perusahaan merupakan faktor penting yang harus dipertimbangkan sebelum mengambil keputusan untuk menetapkan besarnya dividen yang akan dibayarkan kepada para pemegang saham. Oleh karena dividen merupakan cash flow, maka semakin kuatnya posisi kas atau likuiditas perusahaan berarti semakin besar kemampuan membayar dividen (Riyanto, 2001). Debt to Equity Ratio (DER) merupakan rasio hutang terhadap modal. Rasio ini mengukur seberapa jauh perusahaan dibiayai oleh hutang, dimana semakin tinggi nilai rasio ini menggambarkan gejala yang kurang baik bagi perusahaan (Sartono 2001: 66).

Peningkatan hutang pada gilirannya akan mempengaruhi besar kecilnya laba bersih yang tersedia bagi para pemegang saham termasuk dividen yang diterima karena kewajiban untuk membayar hutang lebih diutamakan daripada pembagian dividen. Retun On Assets (ROA) menunjukkan kemampuan modal yang diinvestasikan dalam total aktiva untuk menghasilkan laba perusahaan. Semakin tinggi Return on Assets (ROA) maka kemungkinan pembagian dividen juga semakin banyak (Sartono, 2001). Perusahaan besar dengan total assets yang tinggi dan keuntungan yang teratur dapat dengan mudah masuk ke dalam pasar modal atau memperoleh macam-macam 
dana dari luar untuk pembiayaan. Perusahaan yang sudah mantap tersebut akan mempunyai tingkat dividen yang lebih tinggi dibandingkan dengan perusahaan kecil atau yang masih baru (Marlina, 2009).

Perusahaan yang keuntungannya relatif teratur sering kali dapat memperkirakan bagaimana keuntungan dikemudian hari. Maka perusahaan seperti itu kemungkinan besar akan membagikan keuntunganya dalam bentuk dividen dengan presentase yang lebih besar dibandingkan dengan perusahaan yang keuntungannya berfluaktif (Sundjaja, 2005).

Perusahaan yang terdaftar di BEI tidak semuanya membagikan dividen kepada para pemegang sahamnya, baik itu dalam bentuk dividen tunai maupun dividen saham. Hal tersebut disebabkan oleh adanya pertimbangan-pertimbangan yang berbeda dalam membuat keputusan kebijakan dan pembayaran dividen dalam setiap perusahaan. Sektor manufaktur merupakan sektor yang paling banyak membagi dividen kepada para pemegang sahamnya dalam kurun periode 2012-2014 dibandingkan sektor lain yang terdaftar di Bursa Efek Indonesia (BEI) selama periode 2012-2014.

Tujuan penelitian ini di antaranya: 1) untuk menguji pengaruh Cash Position (CP) terhadap Dividend Payout Ratio (DPR) pada perusahaan manufaktur yang terdaftar di Bursa Efek Indonesia periode 2012-2014, 2) untuk menguji pengaruh Debt to Equity Ratio (DPR) terhadap Dividend Payout Ratio pada perusahaan manufaktur yang terdaftar di Bursa Efek Indonesia periode 2012-2014, 3) untuk menguji pengaruh Return on Assets (ROA) terhadap Dividend Payout Ratio (DPR) pada perusahaan manufaktur yang terdaftar di Bursa Efek Indonesia periode 2012-2014 dan 4) untuk menguji pengaruh Cash Position, Debt to Equity Ratio, dan Return on Assets terhadap Dividend Payout Ratio secara simultan pada perusahaan manufaktur yang terdaftar di Bursa Efek Indonesia periode 2012-2014.

\section{REVIEW LITERATUR DAN HIPOTESIS}

\section{Landasan Teori}

1. Deviden

Menurut Riyanto (2001) dividen merupakan aliran kas yang dibayarkan kepada para pemegang saham (equity investors). Keuntungan para pemegang saham atau investor dapat berupa dividen dan capital gain. Keuntungan yang didapat dari selisih lebih antara harga jual saham dengan harga beli saham disebut capital gain.

\section{Cash Position}

Posisi kas merupakan rasio kas akhir tahun dengan earnings after tax. Posisi kas atau likuiditas perusahaan merupakan faktor yang penting yang harus dipertimbangkan sebelum mengambil keputusan untuk menetapkan besarnya dividen yang akan dibayarkan kepada pemegang saham. Oleh karena itu dividen merupakan cash out flow, maka semakin kuat posisi kas perusahaan, berarti semakin besar kemampuan perusahaan untuk membayar dividen (Riyanto, 2001).

\section{Debt to Equity Ratio}

Prihantoro (2003) menyatakan bahwa debt to equity ratio mencerminkan kemampuan perusahaan dalam memenuhi seluruh kewajibannya, yang ditunjukan oleh beberapa bagian modal sendiri yang digunakan untuk membayar hutang. Oleh karena itu, semakin rendah DER akan semakin tinggi kemampuan perusahaan untuk membayar semua kewajibanya. Semakin besar proporsi utang yang digunakan untuk struktur modal suatu perusahaan, maka akan semakin besar jumlah kewajiban. Peningkatan hutang pada gilirannya 
akan mempengaruhi besar kecilnya laba bersih yang tersedia bagi para pemegang saham termasuk dividen yang akan diterima, karena kewajiban tersebut lebih memprioritaskan pembagian dividen.

\section{Return On Asset}

Ang (1997) dalam Widiyatmoko (2013) menyatakan bahwa Return on assets adalah tingkat keuntungan bersih yang berhasil diperoleh perusahaan dalam menjalankan operasionalnya. Return on Assets diukur dari laba bersih setelah pajak (earning after tax) terhadap total asset yang mencerminkan kemampuan perusahaan dalam penggunaan investasi yang digunakan untuk operasi perusahaan dalam rangka menghasilkan profitabilitas perusahaan. ROA (salah satu ukuran profitabilitas) juga merupakan ukuran efektivitas perusahaan dalam menghasilkan keuntungan dengan memanfaatkan aktiva tetap yang digunakan untuk operasi. Semakin besar ROA menunjukan kinerja perusahaan yang semakin baik karena tingkat pengembalian investasi (return) yang semakin besar.

\section{Penelitian Terdahulu}

Hasil penelitian Pribadi (2012) menunjukkan bahwa ownership dan return on assets berpengaruh positif terhadap dividend payout ratio, sedangkan firm size dan cash position berpengaruh negatif, sedangkan growth opportunity berpengaruh negatif, namun tidak signifikan terhadap dividend payout ratio.

Hasil penelitian Sutoyo (2011) menunjukkan bahwa secara simultan Return On Assets, Current Ratio, Debt to Equity Ratio, Institutional Ownership, Growth, dan Size berpengaruh terhadap Dividend Payout Ratio, sedangkan secara parsial Growth yang berpengaruh terhadap Dividend Payout Ratio, sedangkan Return On Assets, Current Ratio, Debt to Equity Ratio, Institutional
Ownership dan Size tidak berpengaruh terhadap Dividend Payout Ratio.

\section{Hipotesis}

H1: Cash Position berpengaruh terhadap Dividend Payout Ratio pada perusahaan manufaktur yang terdaftar di Bursa Efek Indonesia periode 2012-2014.

H2: Debt to Equity Ratio berpengaruh terhadap Dividend Payout Ratio pada perusahaan manufaktur yang terdaftar di Bursa Efek Indonesia periode 2012-2014.

H3: Return on Assets berpengaruh terhadap Dividend Payout Ratio pada perusahaan manufaktur yang terdaftar di Bursa Efek Indonesia periode 2012-2014.

H4: Cash Position, Debt to Equity Ratio dan Return on Assets berpengaruh terhadap Dividend Payout Ratio pada perusahaan manufaktur yang terdaftar di Bursa Efek Indonesia periode 2012-2014 secara simultan.

\section{METODE PENELITIAN}

\section{Populasi dan Sampel}

Populasi adalah wilayah generalisasi yang terdiri dari obyek atau subyek yang mempunyai kualitas dan karakteristik tertentu yang ditetapkan oleh peneliti untuk dipelajari dan kemudian ditarik kesimpulan (Sugiyono, 2007). Dalam penelitian ini populasi yang diambil sebagai bahan penelitian adalah perusahaan manufaktur yang terdaftar di Bursa Efek Indonesia periode 2012-2014.

Sampel adalah bagian dari jumlah dan karakteristik yang dimiliki oleh populasi. Sampel dalam penelitian ini diambil secara purposive sampling yaitu penentuan sampel dengan pertimbangan kriteria tertentu. Kriteria sampel dalam penelitian ini adalah: 
a. Perusahaan manufaktur yanglistingdi Bursa Efek Indonesia selamaperiode penelitian, (2012-2014).

b. Perusahaan yang memiliki data keuangan yang lengkap selama periodepenelitian, yaitu 2012-2014.

c. Perusahaan yang selalu membagikan dividen selama periode penelitian, yaitu 2012-2014.

\section{Definisi Operasional}

1. Variabel Independen

a. Cash Position $\left(\mathrm{X}_{1}\right)$

Cash Position dihitung berdasarkan perbandingan antara saldo

kas akhir dengan laba bersih setelah pajak

Rumus:

Cash position $=\frac{\text { Saldo Kas Akhir }}{\text { Laba Bersih Setelah pajak }}$

b. Debt to Equity Ratio $\left(\mathrm{X}_{2}\right)$

Debt to Equity Ratio (DER) merupakan rasio hutang terhadap modal sendiri. Rasio ini mengukur seberapa besar perusahaan dibiayai oleh hutang dibanding dengan modal sendiri.

Rumus:

$$
\text { DER }=\frac{\text { Total Hutang }}{\text { Total Modal Sendiri }}
$$

c. Return on Assets $\left(\mathrm{X}_{3}\right)$

$\begin{array}{lll}\text { Return on } & \text { Assets }\end{array}$

dihitungberdasarkanperbandinganlababersihsetelahpajakterhadap

total aktiva yang dimilikiperusahaan.

Rumus:

$\mathrm{ROA}=\frac{\text { Lababersihsetelahpajak }}{\text { Total aktiva }}$

2. Variabel Dependen

Dividend Payout Ratio diukur dengan membandingkan dividen kas per lembar saham terhadap laba yang diperoleh per lembar saham. Variabel dependen yaitu variabel yang dipengaruhi atau yang menjadi akibat, Karena adanya variabel bebas. Variabel dependen dalam penelitian ini adalah Dividend payout ratio (DPR).

\section{Uji Analisis Deskriptif}

Metode analisis deskriptif merupakan suatu metode analisis dimana data-data yang dikumpulkan dan digolongkan kemudian dianalisis dan dipresentasikan secara objektif. Metode analisis keuangan pada penelitian ini menggunakan perhitungan dari rasio-rasio keuangan, yaitu cash position, Growth Potential, Return on Equity, Debt to Equity, firm, size, investement dan dividend payout ratio. Dimana data-data tersebut diambil dari Bursa Efek Indonesia dan kemudian diolah.

\section{Uji Instrumen}

\section{Uji Validitas}

a. Normalitas

Tujuan normalitas adalah untuk mengetahui apakah distribusi sebuah data mengikuti atau mendekati distribusi normal (Helmi et al, 2005). Uji normalitas dilakukan dengan menggunakan tingkat signifikan $10 \%$ maka jika nilai asymp.sig (tailed) di atas nilai signifikan $10 \%$ artinya variabel residual berdistribusi normal (Helmi et al, 2005).

b. Autokorelasi

Menguji autokorelasi dalam suatu model bertujuan untuk mengetahui ada tidaknya korelasi antara variabel pengganggu pada periode tertentu dengan variabel sebelumnya (Sujarweni, 2007).

Untuk mendeteksi adanya autokorelasi digunakan nilai Durbin Watson, adapun kriteria pengujian sebagai berikut: (Handoko, 2008).

Jika nilai $\mathrm{D}-\mathrm{W}$ di atas 0 maka di bawah 1,5 berarti ada Autokorelasi positif.

Jika nilai $\mathrm{D}-\mathrm{W}$ di atas 1,5 dan di bawah 2,5 berarti tidak ada Autokorelasi. 
Jika nila D-W di atas 2,5 dan di bawah 4 berarti ada autokorelasi negatif.

Teknik pengujian autokorelasi dalam Durbin Watson-test. Dengan pengambilan keputusan juga dapat dilakukan dengan membandingkan nilai uji D-W (d) dengan nilai table $\mathrm{D}-\mathrm{W}$ (dL dan $\mathrm{Du}$ ). Dengan kriteria jika du $<$ dhitung $<4$ - du maka tidak terjadi autokorelasi.

c. Heteroskedastisitas

Uji heteroskedasitas bertujuan untuk menguji apakah dalam model regresi terdapat ketidaksamaan varian dari residual satu pengamatan ke pengamatan lainya, jika varian dari residual satu pengamatan ke pengamatan lain tetap, maka terjadi homokesdasitas dan jika berbeda disebut heteroskedasitas. Model regresi yang baik adalah tidak terjadi heteroskedasitas (Helmi et al, 2007).

d. Multikolinieritas

Uji multikolinearitas bertujuan menguji apakah model regresi ditemukan adanya kolerasi antara variabel bebas atau independen (Ghozali, 2005). Hubungan linear antara variabel inilah yang disebut dengan multikolinearitas (Nachrowi, 2006). Model regresi yang baik seharusnya tidak terjadi korelasi antara variabel independen. Uji multikolinearitas menggunakan kriteria nilai tolerance di atas 0,1 dan nilai variance inflation factor (VIF) $>10 \%$, maka terjadi masalah multikolinearitas yang serius (Helmi et al, 2007).

\section{Teknik Analisis Data}

1. Analisis Regresi Berganda

$$
\mathrm{Y}=\mathrm{a}+\mathrm{b}_{1} \mathrm{X}_{1}+\mathrm{b}_{2} \mathrm{X}_{2}+\mathrm{b}_{3} \mathrm{X}_{3}
$$

Dimana:

$$
\begin{aligned}
& \mathrm{Y}=\text { Dividend Payout Ration }(\mathrm{DPR}) \\
& \mathrm{a}=\text { Konstanta } \\
& \mathrm{X}_{1}=\text { cash Position }(\mathrm{CP}) \\
& \mathrm{X}_{2}=\text { Debt to Equity Ratio (DER) } \\
& \mathrm{X}_{3}=\text { Return on Assets (ROA) } \\
& \mathrm{b}_{1,2,3}=\text { koefisien regresi variabel } \mathrm{X}_{1,2,3}
\end{aligned}
$$

\section{Uji Hipotesis}

\section{Uji Parsial (Uji T)}

Pengujian ini dilakukan untuk menguji apakah setiap variabel bebas mempunyai pengaruh yang signifikan terhadap variabel terikat. Kriteria pengambilan keputusan pada uji-t ini adalah:

$\mathrm{H} 0$ diterima jika $\mathrm{t}$ hitung $<\mathrm{t}$ tabel. $\mathrm{H} 1$ diterima jika $\mathrm{t}$ hitung $>\mathrm{t}$ tabel.

2. Uji Simultan (Uji F)

Pengujian ini dilakukan untuk mengetahui apakah variabel bebas secara serempak mempunyai pengaruh yang signifikan terhadap variabel terikat. Kriteria penilaian hipotesis pada uji-F ini adalah:

Terima $\mathrm{H} 0$ bila $\mathrm{F}$ hitung < $\mathrm{F}$ tabel.

Tolak H0 bila F hitung > F tabel.

3. Uji Koefisien Determinasi

Analisis koefisien determinasi dalam regresi linear berganda digunakan untuk mengetahui persentase sumbangan pengaruh variabel bebas (X1, X2....Xn) secara serentak terhadap variabel terikat $(\mathrm{Y})$. Koefisien determinasi (R2) pada intinya mengukur seberapa jauh kemampuan model dalam menerangkan variasi variabel terikat. Nilai koefisien determinasi adalah di 
antara 0 sampai dengan 1. Nilai R2, berarti kemampuan variabel-variabel bebas dalam menjelaskan variasi variabel terikat amat terbatas. Nilai yang mendekati 1 berarti variabelvariabel bebas memberikan hampir semua informasi yang dibutuhkan untuk memprediksi variasi variabel terikat.

\section{HASIL PENELITIAN DAN PEMBAHASAN}

\section{Hasil Analisis Deskriptif}

\begin{tabular}{|l|l|l|l|l|l|l|}
\multicolumn{7}{|c|}{ Statistik Deskriptif Variabel Penelitian } \\
\hline \multirow{2}{*}{} & N & Minimum & Maximum & \multicolumn{2}{l|}{ Mean } & $\begin{array}{l}\text { td. } \\
\text { Deviation }\end{array}$ \\
\cline { 3 - 7 } & & & & & & \\
& & & & & & \\
\hline Ln_DPR & 51 & -7.292 & 6.821 & -.55913 & .359358 & 2.566328 \\
Ln_CP & 51 & 2.064 & 6.683 & 4.58016 & .153216 & 1.094179 \\
Ln_DER & 51 & -1.833 & .536 & -.37199 & .092650 & .661655 \\
Ln_ROA & 51 & -2.659 & 6.888 & 1.63895 & .395773 & 2.826385 \\
Valid N & 51 & & & & & \\
(listwise) & & & & & & \\
\hline
\end{tabular}

Tabel di atas merupakan hasil dari uji statistik deskriptif data penelitian. Dari tabel statistik deskriptif tersebut dapat dijelaskan bahwa nilai mean yang terbesar terdapat pada variabel Ln_Cp (X1) sebesar 4.58016 dan yang terkecil pada Ln_DPR (Y) sebesar -.55913. Sedangkan standar deviasi terbesar terdapat pada variabel Ln_ROA (X3) sebesar 2.826385 dan yang terkecil terdapat pada variabel Ln_DER (X2) sebesar .661655, dengan demikian dapat diketahui bahwa pada variabel Ln_CP nilai-nilainya relatif lebih seragam dibandingkan dengan variabel lainnya.

\section{Hasil Penelitian}

1. Hasil Uji Asumsi Klasik

a. Normalitas

\section{Hasil Uji Normalitas}

One-Sample Kolmogorov-Smirnov Test

\begin{tabular}{|c|c|c|}
\hline & $\begin{array}{l}\text { Unstandardiz } \\
\text { ed Residual }\end{array}$ \\
\hline \multicolumn{2}{|l|}{$\mathrm{N}$} & 51 \\
\hline \multirow{3}{*}{$\begin{array}{l}\text { Normal } \\
\text { Parameters }\end{array}$} & Mean & $0 \mathrm{E}-7$ \\
\hline & Std. & \\
\hline & Deviation & 2.32494652 \\
\hline Most & Absolute & .145 \\
\hline Extreme & Positive & .145 \\
\hline Differences & Negative & -.129 \\
\hline \multicolumn{2}{|c|}{ Kolmogorov-Smirnov Z } & 1.032 \\
\hline \multicolumn{2}{|c|}{ Asymp. Sig. (2-tailed) } & .237 \\
\hline
\end{tabular}

Suatu data dikatakan

terdistribusi normal jika nilai

probabilitas (p) uji One-Sample

Kolmogorov Smirnoz-Z $>0.1$.

Berdasarkan hasil output di atas dapat diketahui bahwa nilai probabilitas sebesar 0.237 karena nilai probabilitas > 0.1 maka dapat disimpulkan bahwa data dalam penelitian ini berdistribusi normal.

b. Autokorelasi

\section{Hasil Uji Autokorelasi}

\begin{tabular}{|l|}
\hline Durbin Watson \\
\hline 1.865 \\
\hline
\end{tabular}

Berdasarkan output di atas, diketahui nilai Durbin-Watson sebesar 1.865 , selanjutnya nilai ini akan dibandingkan dengan nilai tabel signifikansi 10\%, jumlah observasi $\mathrm{N}=51$ dan jumlah variabel independen $3(\mathrm{~K}=3)=3.51=153$, maka diperoleh nilai dU sebesar 1.6754. Nilai Durbin-Watson sebesar 1.865 lebih besar dari batas atas (dU) yakni 1.6754 dan kurang dari (4-dU) 4-1.6754 = 2.3246 
sehingga dapat disimpulkan bahwa tidak terjadi autokorelasi.

c. Heteroskedastisitas

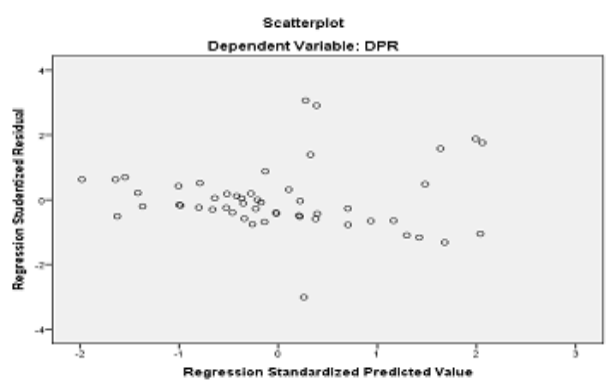

Berdasarkan diagram pencar di atas, maka dapat dilihat bahwa sebaran titik-titik acak (random) tidak membentuk suatu pola atau tren garis tertentu, maka dapat disimpulkan tidak terjadi heteroskedastisitas pada model regresi.

d. Multikolinieritas

Hasil Uji Mulitikolinearitas

\begin{tabular}{|l|l|l|}
\hline Variabel & Tolerance & VIF \\
\hline Ln_CP & .995 & 1.005 \\
\hline Ln_DER & .984 & 1.018 \\
\hline Ln_ROA & .981 & 1.020 \\
\hline
\end{tabular}

Dari hasil perhitungan di atas dengan dibantu SPSS 20 menunjukkan bahwa masing-masing variabel mempunyai nilai tolerance di atas 0,1 dan nilai VIF kurang dari 10. Dengan demikian, data yang diolah menunjukkan tidak adanya gejala multikolinearitas.

2. Hasil Uji Regresi Linier Berganda Hasil Uji Analisis Regresi Berganda

\begin{tabular}{|c|c|c|c|c|c|}
\hline \multicolumn{6}{|c|}{ Coefficients ${ }^{\mathrm{a}}$} \\
\hline \multirow[t]{3}{*}{ Model } & \multirow{2}{*}{\multicolumn{2}{|c|}{$\begin{array}{l}\text { Unstandardized } \\
\text { Coefficients }\end{array}$}} & \multirow{3}{*}{$\begin{array}{l}\text { Standardized } \\
\text { Coefficients } \\
\text { Beta }\end{array}$} & \multirow[t]{3}{*}{$\mathrm{T}$} & \multirow[t]{3}{*}{ Sig. } \\
\hline & & & & & \\
\hline & B & Std. Error & & & \\
\hline (Constant) & 1.589 & 1.502 & & 1.058 & .295 \\
\hline Ln_CP & -.576 & .311 & -.245 & -1.852 & .070 \\
\hline Ln_DER & .005 & .517 & .001 & .010 & .992 \\
\hline Ln_ROA & .299 & .121 & .329 & 2.465 & .017 \\
\hline
\end{tabular}
$0.299 \mathrm{X} 3$
Adapun penjelasan dari model regresi di atas dapat dijabarkan sebagai berikut:

a. Nilai konstanta sebesar 1.589 menunjukkan bahwa jika tidak ada cash position, debt to equity ratio, dan return on asset maka deviden payout ratio sebesar 1.589

b. Nilai koefisien regresi cash position ( $\beta 1)$ sebesar 0.576 menujukkan bahwa saat cash position naik sebesar satu satuan maka deviden payout ratio akan naik sebesar 0.576 . Sebaliknya saat cash position turun satu satuan maka deviden payout ratio akan turun sebesar 0.576 .

c. Nilai koefisien regresi debt to equity ratio $(\beta 2)$ sebesar 0.005 menujukkan bahwa saat debt to equity ratio naik sebesar satu satuan maka deviden payout ratio akan naik sebesar. Sebaliknya saat debt to equity ratio turun satu satuan maka deviden payout ratio akan turun sebesar 0.005 .

d. Nilai koefisien regresi return on asset ( $\beta 3$ ) sebesar 0.299 menujukkan bahwa saat return on asset naik sebesar satu satuan maka deviden payout ratio akan naik sebesar 0.299. Sebaliknya saat return on asset turun satu satuan maka deviden payout ratio akan turun sebesar 0.299.

\section{Hasil Uji Parsial (Uji T)}

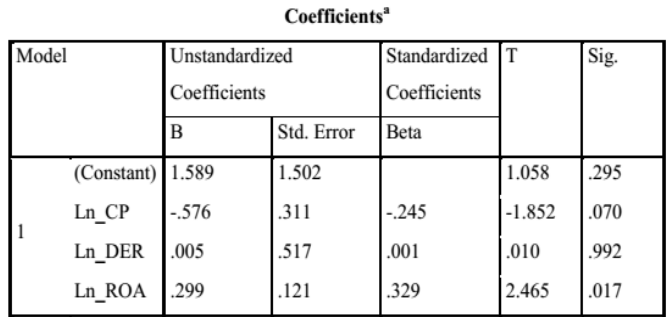

a. Untuk variabel cash position, karena nilai signifikan < alpha yaitu $0.070<$ 0.1 maka $\mathrm{Ha}$ diterima, berarti variabel cash position secara parsial berpengaruh terhadap variabel 
deviden payout ratio pada perusahaan manufaktur yang terdaftar di Bursa Efek Indonesia periode 2012-2014, berarti H1 terdukung.

b. Untuk variabel debt to equity ratio, karena nilai signifikan < alpha yaitu $0.992>0.1$ maka H0 diterima, berarti variabel debt to equity ratio secara parsial tidak berpengaruh terhadap variabel deviden payout ratio pada perusahaan manufaktur yang terdaftar di Bursa Efek Indonesia periode 2012-2014, berarti $\mathrm{H} 2$ tidak terdukung.

c. Untuk variabel return on asset, karena nilai signifikan > alpha yaitu $0.017<0.1$ maka Ha diterima, berarti variabel return on asset secara parsial berpengaruh terhadap variabel deviden payout ratio pada perusahaan manufaktur yang terdaftar di Bursa Efek Indonesia periode 2012-2014, berarti H3 terdukung.

\section{Hasil Uji Simultan (Uji F)}

ANOVA ${ }^{\mathrm{a}}$

\begin{tabular}{|l|l|l|}
\hline Model & F & Sig. \\
\hline $\begin{array}{l}\text { Regression } \\
\text { Residual } \\
\text { Total }\end{array}$ & 3.422 & $.025^{b}$ \\
\hline
\end{tabular}

Berdasarkan hasil analisis perhitungan pada output SPSS 20. Diperoleh nilai signifikansi $0.025<$ alpha 0.1 maka Ha diterima. Sehingga dapat disimpulkan bahwa variabel independen yaitu cash position, debt to equity ratio dan return on asset dalam penelitian ini secara bersama-sama mempunyai pengaruh yang signifikan terhadap variabel dependen yaitu deviden payout ratio pada perusahaan manufaktur yang terdaftar di Bursa Efek Indonesia periode 2012-2014.
5. Hasil Uji Koefisien Determinasi

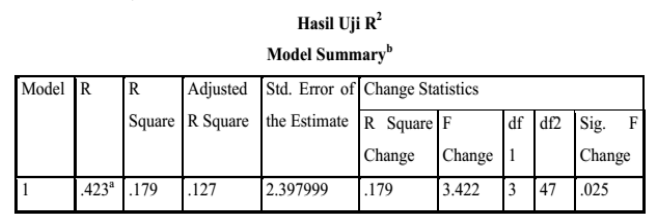

Koefisien determinasi bertujuan untuk mengetahui seberapa besar kemampuan variabel independen menjelaskan variabel dependen. Dalam output SPSS 20 koefisien determinasi terletak pada tabel Model Summary dan tertulis R Square sebesar 0.179. Hal ini berarti bahwa $17.9 \%$ perubahan variabel dependen (devidend payout ratio) mampu dijelaskan oleh variabel independen cash position, debt to equity ratio dan return on asset dan sisanya $82.1 \%$ dijelaskan oleh variabel lain diluar variabel yang digunakan dalam penelitian.

\section{Pembahasan}

Berdasarkan pada hasil output SPSS, hasil penelitian pada hipotesis pertama menunjukkan bahwa cash position berpengaruh terhadap dividend payout ratio dengan nilai signifikan sebesar 0.070. Karena nilai signifikan lebih $<0,1$ maka hipotesis satu diterima. Hal ini berarti cash position berpengaruh terhadap dividend payout pada perusahaan manufaktur yang terdaftar di Bursa Efek Indonesia periode 2012-2014, artinya semakin meningkatnya cash position dapat meningkatkan keyakinan para investor untuk memperoleh dividen tunai atau cash dividen yang diharapkan oleh investor. Hasil penelitian ini konsisten dengan penelitian Marlina (2009) yang menyatakan bahwa cash position, debt to equity ratio dan return on assets berpengaruh terhadap dividend payout ratio. Namun hasil penelitian tersebut berbeda dengan penelitian yang dilakukan oleh Pribadi (2012) yang menyatakan bahwa cash position tidak berpengaruh terhadap dividend payout ratio.

Berdasarkan pada hasil output SPSS, hasil penelitian pada hipotesis 
kedua menunjukkan bahwa debt to equity ratio berpengaruh terhadap dividend payout ratio dengan nilai signifikan 0.992. Karena nilai signifikan lebih $>0,1$ maka hipotesis dua ditolak. Hal ini berarti debt to equity ratio tidak berpengaruh terhadap dividend payout ratio pada perusahaan manufaktur yang terdaftar di Bursa Efek Indonesia periode 2012-2014, hasil penelitian ini tidak sesuai dengan teori yang dikemukan oleh oleh Sartono (2001) yaitu semakin tinggi DER semakin berkurang kemampuan perusahaan membayar dividen sebaliknya semakin turun DER semakin tinggi kemampuan perusahaan membayar dividen. Hasil penelitian ini konsisten dengan penelitian Marlina (2009), Arsanda (2011) dan Basuki (2012) yang menyatakan bahwa cash position, debt to equity ratio dan return on asset tidak berpengaruh terhadap dividend payout ratio. Namum hasil penelitian tersebut berbeda dengan penelitian yang dilakukan oleh Primawestri (2011) dan Fajriyah (2011), menunjukkan bahwa Return on Assets, Debt to Equity Ratio, Management, Ownership, Free Cash Flow, dan Size mempunyai pengaruh terhadap Dividend Payout Ratio.

Berdasarkan pada hasil output SPSS hasil penelitian pada hipotesis ketiga menunjukkan bahwa return on assets berpengaruh signifikan terhadap dividend payout ratio dengan nilai signifikan sebesar 0.017 karena nilai signifikan lebih $<0,1$, maka hipotesis tiga diterima. Hal ini menunjukkan bahwa Return on assets berpengaruh terhadap dividend payout ratio pada perusahaan manufaktur yang terdaftar di Bursa Efek Indonesia periode 2012-2014, artinya semakin besar ROA menunjukkan kinerja perusahaan yang semakin baik. Hasil penelitian ini konsisten dengan penelitian Marlina (2009), Basuki (2012) dan Primawestri (2011), menunjukkan bahwa cash position, debt to equity ratio, return on asset dan net profit margin (NPM) mempunyai pengaruh terhadap dividend payout rati.
Laksono (2006), Ripastoko (2007) menunjukkan bahwa Return on Assets, Sales Growth, Assets, Growth, Cash Flow \& Liquiditas tidak berpengaruh terhadap dividend payout ratio. Namun hasil penelitian tersebut berbeda dengan penelitian Laksono (2006), Ripastoko (2007) menunjukkan bahwa Return on Assets, Sales Growth, Assets, Growth, Cash Flow \& Liquiditas tidak berpengaruh terhadap dividend payout ratio.

Berdasarkan pada hasil output SPSS hasil penelitian pada hipotesis keempat menunjukkan bahwa cash position, debt to equito ratio dan return on assets berpengaruh terhadap dividend payout ratio dengan nilai signifikan 0,025 karena nilai signifikan $<0,10$, maka hipotesis keempat diterima. Hal ini menunjukkan bahwa Cash position, debt to equity ratio dan return on assets berpengaruh terhadap dividend payout ratio pada perusahaan manufaktur yang terdaftar di Bursa Efek Indonesia periode 2012-2014. Hasil penelitian ini konsisten dengan penelitian Sutoyo, Prasetio (2011), menunjukkan bahwa return on assets, current ratio, dan debt to equity ratio, Kepemilikan institusi, pertumbuhan perusahaan, dan ukuran perusahaan secara simultan berpengaruh signifikan terhadap dividend payout ratio.

\section{KESIMPULAN DAN SARAN}

\section{Kesimpulan}

1. Cash position berpengaruh terhadap dividend payout ratio pada perusahaan manufaktur yang terdaftar di Bursa Efek Indonesia periode 2012-2014.

2. Debt to equity ratio tidak berpengaruh terhadap dividend payout ratio pada perusahaan manufaktur yang terdaftar di Bursa Efek Indonesia periode 20122014.

3. Return on asset berpengaruh terhadap dividend payout ratio pada perusahaan 
manufaktur yang terdaftar di Bursa Efek Indonesia periode 2012-2014.

4. Cash position, debt to equity ratio dan return on assets secara simultan berpengaruh terhadap dividend payout ratio pada perusahaan manufaktur yang terdaftar di Bursa Efek Indonesia periode 2012-2014.

\section{Saran}

1. Bagi investor yang ingin berinvestasi dalam bentuk saham dan menyukai keuntungan dari pembagi dividen bisa menggunakan rasio cash position, debt to equity ratio dan return on asset untuk memprediksi kemampuan emiten untuk membagikan dividen.

2. Bagi peneliti selanjutnya, hasil penelitian ini dapat dijadikan referensi untuk melakukan penelitian lanjutan khususnya di bidang kajian yang sama.

\section{DAFTAR PUSTAKA}

Ang, R. (1997). Buku Pintar Pasar Modal Indonesia. Jakarta: Mediasoft.

Arsanda, Septiani Arie. (2011). Analisis pengaruh return on asset, debt to equity ratio, growth, firm size, dan cash ratio terhadap dividend payout ratio (studi empiris pada perusahaan manufaktur yang listed di bei periode 2005-2008. Skripsi. Fakultas Ekonomi Universitas Diponerogo Semarang.

Basuki, Arief. (2012). Analisis pengaruh cash ratio, debt to total asset ratio, debt to equity ratio, return on asset, dan net profit margin terhadap dividend payout ratio. Skripsi. Fakultas Ekonomi Universitas Diponegoto Semarang.

Darmadji, Tjiptono dan Hendy $\mathrm{M}$. Fakhruddin. (2006). Pasar Modal di Indonesia: Pendekatan Tanya Jawab. Edisi Kedua. Jakarta: Salmba Empat.

Fajriyah, Nasim. (2011). Analisis Pengaruh ROE, DER, Management Ownership, Free Cash Flow, Dan Size Terhadap Dividend Payout Ratio Pada Perusahaan - Perusahaan Manufaktur Yang Terdaftar Di Bursa Efek Indonesia (BEI) Tahun 2006 - 2009. Skripsi. Universitas Diponegoro Semarang.

Helmi, et al. (2007). Analisis data Penelitian (Menggunakan Program SPSS). Medan: USU Press.

Laksono, Bagus. (2006). Analisis pengaruh return on asset, sales growth, asset growth, cash flow dan likuiditas terhadap dividend payout ratio (perbandingan pada perusahaan multi national company dan domestic corporation yang listed di bursa efek Jakarta periode 20022004. Tesis. Universitas Diponegoro. Marlina, Lisa dan Clara Danica. (2009). Analisispengaruh Cash Position, Debt to Equity Ratio, dan Return on Assets terhadap Dividend Payout Ratio. Jurnal Manajemen Bisnis.

Nachrowi, D. (2006). Pendekatan Populer dan Praktis Ekonomi: Untuk Analisis Ekonomi dan Keuangan. Jakarta: Lembaga Penerbit Fakultas Ekonomi Universitas Indonesia.

Pribadi, Satria Anggit dan R. Djoko Sampurno. (2012). Analisis Pengaruh Cash Position, Firm Size, Growth Opportunity, Ownership, Dan Return On Asset Terhadap Dividend Payout Ratio. Diponegoro Journal Of Management. Volume 1, Nomor 1.

Prihantoro. (2003). Estimasi Pengaruh Dividend Payout Ratio pada 
perusahaan Publik di Indonesia. Jurnal Ekonomi dan Bisnis. Vol. 14. No. 1.

Primawestri, Laksmi. (2011). Analisis Faktor-faktor yang mempengaruhi dividend payout ratio. Skripsi. Universitas Diponegoro Semarang.

Risaptoko, RB,A (2007). Analisis Pengaruh Cash Ratio, Debt to total asset, AssetGrowth, Firm size, dan Return on Asset terhadap Dividen d Payout Ratio (Studi Komparatif pada Perusahaan yang Listed di BEJ yang Sahamnya Ikut Dimiliki Manajemen dan Yang Sahamnya Tidak Dimiliki Manajemen Periode Tahun 2002-2005. Tesis yang Tidak Dipublikasikan.

Riyanto, Bambang. (2001). Dasar-Dasar Pembelanjaan Perusahaan. Yogyakarta: BPFE:

Sartono, Agus. (2001). Manajemen Keuangan "Teori dan Aplikasi. Edisi Keempat. Yogyakarta: BPFE.

Sugiyono. (2007). Metode Penelitian Bisnis. Cetakkan Kesepuluh. Baandung: Alfabeta.

Sundjaja, Ridwan S. dan Inge Barlian. (2005). Manajemen Keuangan II. Edisi Keempat. Bandung: Literata Lintas Media.

Sutoyo, et al. (2011). Faktor-Faktor yang Mempengaruhi Dividend Payout Ratio pada Perusahaan Jasa Keuangan. Jurnal Keuangan dan Perbankan. Vol 5 No1.

Widyatmoko, Harisya. (2013). Analisis Pengaruh Cash Position, Debt To Equity Ratio dan Return On Asset Terhadap Deviden Payout Ratio Pada Perusahaan Manufaktur Yang Terdaftar di Bursa Efek Indonesia. Skripsi. Yogyakarta: Universitas Ahmad Dahlan. 